\title{
Job Satisfaction of Home Appliance Showroom Salespersons in Khulna City, Bangladesh
}

\author{
Md. Anisur Rahman \\ Department of Business Administration, North Western University, Khulna-9100, Bangladesh
}

\begin{abstract}
The main objective of the study is to present the job satisfaction level of salespersons working for various home appliance showrooms in Khulna City and to identify the factors impacting job satisfaction. In this study, job satisfaction for showroom salespersons was measured with 8 independent factors. The main finding of the study is that almost three-fourth of the salespersons working for various home appliance showrooms in Khulna City are satisfied with their job, taking everything into account. Another important finding of the study is that top three ranked factors are directly/indirectly financial related, while the bottom three ranked factors are directly nonfinancial. However, the showroom salespersons are very satisfied for "relation with and support from colleagues" with the highest mean value of 4.28 , while the lowest mean value (2.33) for "benefit for overtime/extra work hours". Therefore, organizations and showroom managers need to turn their attention to provide different kinds of facilities to their employees, if they want to enhance their businesses.
\end{abstract}

Keywords: Job satisfaction, home appliance showroom, salesperson, Khulna city.

DOI: $10.7176 / \mathrm{EJBM} / 11-30-04$

Publication date:October $31^{\text {st }} 2019$

\section{Introduction}

Job satisfaction represents one of the most complex areas for the managers to manage their employees and workers in organizations. All over the world, it is a well-recognized fact that a person with a high level of job satisfaction has a positive attitude towards the job, while a person who is dissatisfied with the job has a negative attitude. When the managers speak about employee attitude, they usually are referring to their employee job satisfaction. Employees' job satisfaction (or simply job satisfaction) has surfaced as a major issue in almost all organization. Job satisfaction is in regard to one's feelings or state of mind regarding to the nature of their work (Tasnim, 2006). According to human behavior, people are more interested to work in those companies and service organizations from where they get mental satisfaction. The term "Job Satisfaction" means individuals emotional reaction to job. It is a positive emotional state that occurs when a person's job seem to fulfill important job values provided. Job satisfaction describes how content an individual is with his or her job. There are a variety of factors that can influence a person's level of job satisfaction. Some of these factors include the level of pay and benefits, the perceived fairness of the promotion system within a company, the quality of the working conditions, leadership and social relationships, the job itself (Judge and Church, 2000; Jurgensen, 1978). Other influences on satisfaction include the management style and culture, employee involvement, empowerment and autonomous workgroups. The happier people are within their job, the more satisfied they are said to be.

Job satisfaction is a matter of growing interest, for it is concerned with the individual's work performance and organizational efficiency. Various studies reveal that job satisfaction plays an important role to an employee in terms of health and well-being (Khaleque, 1984) and to an organization in terms of it's efficiency, productivity, employee relations, absenteeism and turnover (Mowday, 1981; Haque and Islam, 2003). In any organization three groups of manager namely top, mid and lower level are directly or indirectly responsible for' its effective management, proper supervision and higher productivity. The face of any organization is its sales force. Sales force is linking between companies and customer. Companies spend a considerable amount of time and money on sales force rather than on any other promotional activity. While sales force management is an important aspect of organizational processes directly linked to marketing and sales department, Human Resources department is initially responsible for the right recruits, and later on their proper maintenance, development and retention. A well-managed business organization, especially marketing and sales department, considers the better sales persons as the primary source of product promotion and sales gains, where sales persons play a crucial roles regarding to customers' in store purchase behavior. The organization considers sales forces rather than capital as the core foundation of the business and contributors to firm development. To ensure the achievement of firm goals, the organization creates an atmosphere of commitment and cooperation for its sales forces through policies that facilitate job satisfaction. Usually satisfaction of human resource finds close links to highly motivated employees. Motivated employees then develop loyalty or commitment to the firm resulting to greater productivity and lower turnover rates. The same is true for sales forces for increasing the sales and customer loyalty.

For home appliance showroom, the consequences of job satisfaction and dissatisfaction are extremely important because of satisfaction of salespersons directly affects the work quality and work behavior, which in turn determines their sales skills and achievement of sales target of that respective showroom. Various studies 
around the globe have demonstrated a large impact of job satisfaction on the motivation of workers, while the level of motivation has an impact on productivity, and on the performance of business organizations. Therefore, the study was conducted to analyze the job satisfaction of salespersons in home appliance showrooms in Khulna.

\section{Objectives of the Study}

The main objective of the study is to present the current job satisfaction level of home appliance showroom salespersons in Khulna City. The specific objectives of the study are:

$>$ to identify the general profile of home appliance showroom salespersons.

$>$ to identify the influential factors that contribute to job satisfaction of home appliance showroom salespersons.

$>$ to assess job satisfaction level of home appliance showroom salespersons.

\section{Scope and Limitations of the Study}

The study was confined to showroom salespersons working for various home appliance brands in Khulna City. Very specifically, this study covered the factors affecting job satisfaction of salespersons in home appliance showrooms in Khulna City. The major factors that affect job satisfaction are work conditions, pay, fairness and promotion, supervisory support/relationship with management, job security, training \& development, organizational culture \& policy, team cohesion etc.; individual factors include age, gender, education etc. These factors are the independent variables and job satisfaction is the dependent variable. Though there are lots of research works on job satisfaction, there is limited research works in the context of home appliance showroom salespersons in Bangladesh. The study findings are just the reflection of job satisfaction of home appliance showroom salespersons in Khulna City, other employees in the showroom are not considered. Only eight (8) factors of job satisfaction were examined for showroom salespersons with forty (40) respondents as sample from Khulna City. Inclusion of more factors and respondents in the sample size from home appliance showrooms in other cities could increase the reliability of the findings.

\section{Literature Review and Theoretical Orientation}

Job satisfaction has been defined as a general attitude toward one's job and a person's feeling of satisfaction on the job, which acts as a motivation to work. It is not the self-satisfaction, happiness or self-contentment but the satisfaction on the job. The term relates to the total relationship between an individual and the employer for which he is paid. It is in regard to one's feelings or state of mind regarding the nature of their work. Job satisfaction is the difference between the amount of rewards employees receive and the amount they believe they should receive (Robbins, 1997). Mobey and Lockey (1970) opined job satisfaction and dissatisfaction are function of the perceived relationship between what one expects and obtains from one's job and how much importance or value one attributes to it.

There has been disagreement among researchers about whether job satisfaction has multiple dimensions. Porter and Lawler (1972) define job satisfaction as a one-dimensional contract; that is, one is generally satisfied or dissatisfied with one's job. In contrast, job satisfaction is multidimensional; that is one may be more or less satisfied with one's supervisor, pay or workplace etc. (Smith et al., 1969). For the purpose of our work, we follow the second opinion and define job satisfaction as an emotional response towards various facets of one's job. A person can be relatively satisfied with one aspect of his/her job and dissatisfied with one or more other aspects. Authors also vary in opinions of what should be these factors or facets. According to Robbins (1997), finding summation of satisfaction regarding different job facets is a sophisticated approach of measuring job satisfaction and the five key elements are: nature of the work, supervision, present pay, promotion opportunities and relation with coworkers. Davis and Newstrom (1997) added 'immediate working condition' along with the above five factors. Other influences on satisfaction include the management style and culture, employee involvement, empowerment and autonomous work position. The satisfaction an employee obtains from work is a function of his/ her individual motives and values, and not only of the objective properties of that job (Siddika, 2012).

One of the biggest preludes to the study of job satisfaction was the Hawthorne studies. These studies (19241933), primarily credited to Elton Mayo of the Harvard Business School, sought to find the effects of various conditions (most notably illumination) on workerse productivity. These studies ultimately showed that novel changes in work conditions temporarily increase productivity (called the Hawthorne Effect). It was later found that this increase resulted, not from the new conditions, but from the knowledge of being observed. This finding provided strong evidence that people work for purposes other than pay, which paved the way for researchers to investigate other factors in job satisfaction. A satisfied employee tends to be absent less often, to make positive contributions and to stay with the organization very eagerly (Hakim, 1993). But a non-satisfied employee may be absent more often, may experience stress that disrupts co-workers, and may be continually looking for another job. Contrary to what a lot of managers believe, however, high levels of job satisfaction do not necessarily lead to higher levels of productivity. One survey indicated that, also contrary to popular opinion, Japanse workers are less 
satisfied with their jobs than their counterparts in the USA (Lincoln, 1989).

Hoppock (1935) describes job satisfaction as, "any combination of psychological, physiological and environmental circumstances that cause any person truthfully to say I am satisfied with my job". There are five job dimensions that represent the most important characteristics of a job about which people have affective responses and those are (Smith et al. 1969):

1. The work itself: The extent to which the job provides the individual with the interesting task, opportunities for learning and the chance of accept responsibility.

2. Pay: The amount of financial remuneration that is received and the degree to which this is viewed as equitable vis-a-vis that of others in the organization.

3. Promotion opportunities: The chance for advancement in the hierarchy.

4. Supervision: The ability is on the supervision to provide technical assistance and behavioral support.

5. Co-Employees: The degree to which follow Employees are technically proficient and socially supportive.

According to Abraham A. Korman (1991), there are two types of variables which determine the job satisfaction of an individual in any organizational settings, namely "organizational variables (occupational level, job content, leadership, pay \& promotional opportunity, and interaction in the workgroup)" and "personal variables (age, education, role perception and sex".

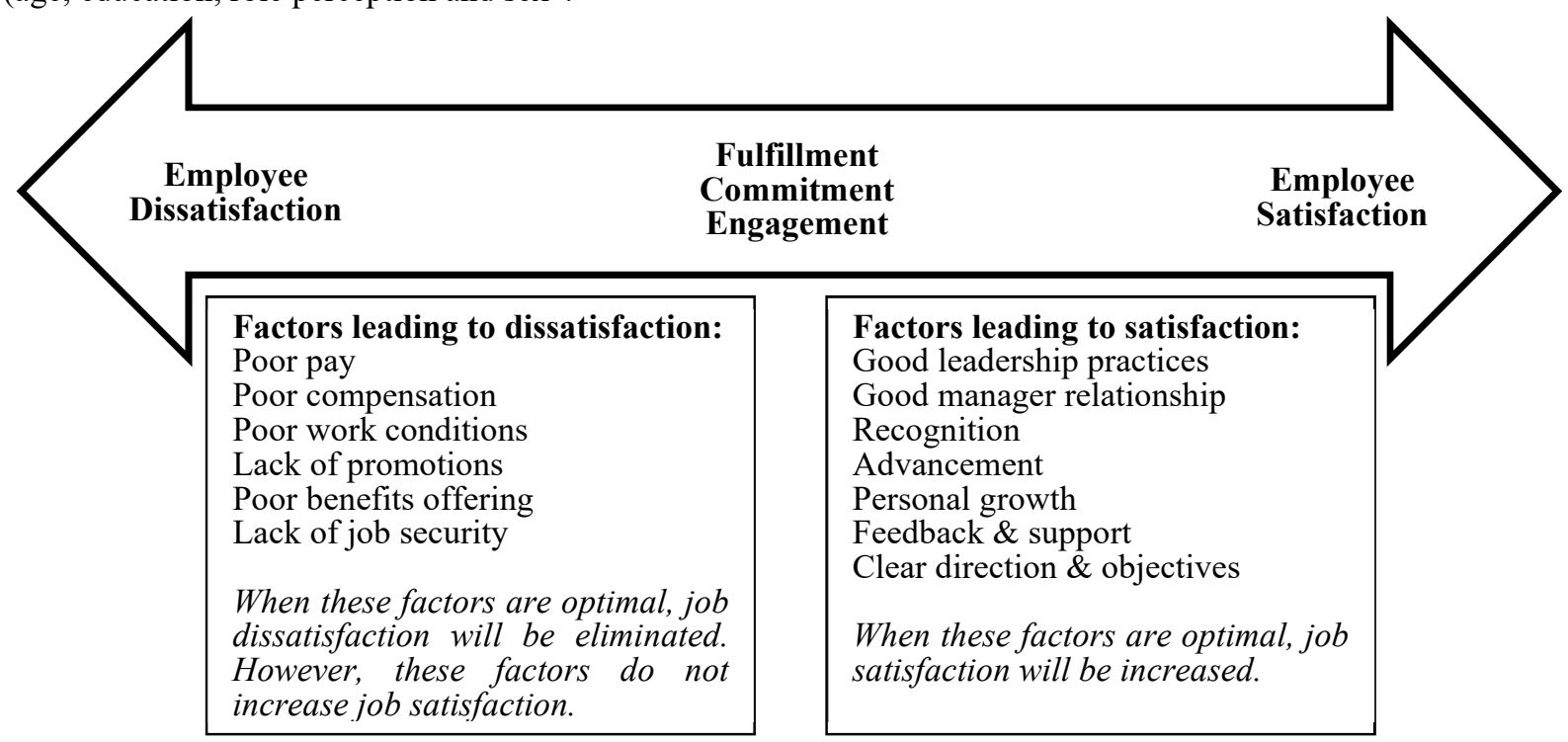

Figure 4.1: Job Satisfaction Model and Leading Factors of Job Satisfaction (Field, J. 2008)

A number of theories exist which relate to job satisfaction. The following are the relevant theories of job satisfaction which are highlighted in brief manner:

Hertzberg's Two Factor Theory: Frederick Herzberg's Two Factor Theory (also known as MotivatorHygiene Theory) attempts to explain satisfaction and motivation in the workplace (Hertzberg, 1966). This theory states that satisfaction and dissatisfaction are driven by different factors-motivation and hygiene factors respectively. When Motivator needs are met, workers will be satisfied; when these needs are not met, workers will not be satisfied. When Hygiene needs are met, workers will not be dissatisfied; when these needs are not met, workers will be dissatisfied. Hygiene factors include quality of supervision, pay, company policies, physical working conditions, relations with others. Motivators are promotion opportunities, opportunities for personal growth, recognition, responsibility and achievement. 


Dissatisfaction
with job

Dissatisfaction with job

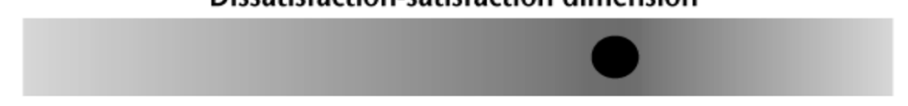

Satisfaction

with job

A. According to the traditional view, a worker is either satisfied or dissatisfied with his or her job.

\begin{abstract}
No satisfaction with job (motivator needs not met)
\end{abstract}

Satisfaction dimension

Dissatisfaction
with job (hygiene
needs not met)

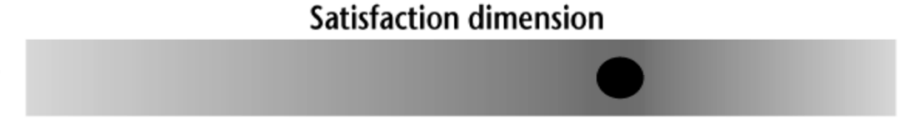

Satisfaction

with job (motivator

needs met)

No dissatisfaction

with job (hygiene needs met)

B. According to Herzberg, a worker can be both satisfied and dissatisfied with his or her job at the same time.

Figure 4.2: Two Views of Job Satisfaction (Hertzberg, 1966)

Affect Theory: Affect Theory by Edwin A. Locke (1976) is arguably the most famous job satisfaction model. The main premise of this theory is that satisfaction is determined by a discrepancy between what one wants in a job and what one has in a job. Further, the theory states that how much one values a given facet of work (e.g. the degree of autonomy in a position) moderates how satisfied/dissatisfied one becomes when expectations are/aren't met. When a person values a particular facet of a job, his satisfaction is more greatly impacted both positively (when expectations are met) and negatively (when expectations are not met), compared to one who doesn't value that facet. To illustrate, if employee A values autonomy in the workplace and employee B is indifferent about autonomy, then employee A would be more satisfied in a position that offers a high degree of autonomy and less satisfied in a position with little or no autonomy compared to employee B. This theory also states that too much of a particular facet will produce stronger feelings of dissatisfaction the more a worker values that facet.

An analytical framework is developed for this study based on the review of the relevant literature. The proposed model aims to assess the variance in different factors of job satisfaction. Once the data will be available, it will help to examine the significance of various factors to the dependent variable of job satisfaction.

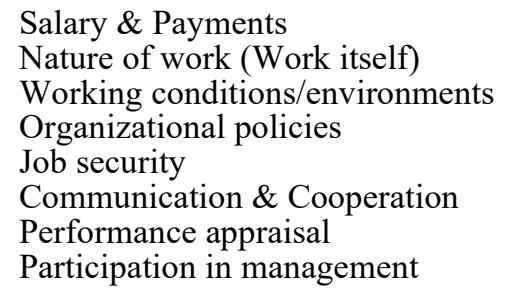

Figure 4.3: Factors to Assess Job Satisfaction of Showroom Salespersons

Though there are also other organizational variables which also effect job satisfaction of home appliance showroom salesperson of Khulna City but for convenience the researcher has only selected the above mentioned eight variables. Job satisfaction is a very important attribute which is frequently measured by organizations. The most common way of measurement is the use of rating scales where employees report their reactions to their jobs. Questions relate to pay, work responsibilities, variety of tasks, promotional opportunities, the work itself and coworkers etc. Some questioners ask yes or no questions while others ask to rate satisfaction on 1-5 scale (where 1 represents "completely dissatisfied" and 5 represents "completely satisfied").

\section{Methodology}

Survey research design was followed for this study and descriptive in nature. The study was a mixture of both qualitative and quantitative analysis based on the collected information from both primary and secondary sources. A total forty (40) individual salespersons (convenience sampling) were selected from five (5) famous home appliance brands (judgmental sampling) in Khulna city for collecting primary data related to job satisfaction. The brand showrooms were: Best Electronics, LG-Butterfly, Walton, Transcom Electronics and Singer (Bangladesh) Ltd. Eight (8) salespersons from each home appliance brand showrooms were interviewed. Primary data were collected through structured questionnaire. A structured, closed-ended questionnaire was given to respondents for collecting their opinion regarding job satisfaction using a 5 points Likert scale which is denoted by $1=$ Completely dissatisfied, 2 = Dissatisfied, $3=$ Neutral, $4=$ Satisfied, and $5=$ Completely satisfied. The respondents were also asked their age, gender, education, years of employment and daily work hours. The questionnaire was developed based on literature of job satisfaction to suit the local context. 


\section{Analysis and Discussion}

Based on the model presented in analytical framework, a structured questionnaire was developed to the level of job satisfaction of home appliance showroom salespersons. The showroom salesperson survey was composed of 23 questions designed to elicit information on job satisfaction. The first part of the questionnaire was based on demographics such as age, gender, education and years of employment. The second part was based on daily work hours and relative important of factors affecting job satisfaction. The questions were based on a 5 points Likert scale and coded as numbered in the methodology section.

6.1 Demographic Characteristics of Showroom Salespersons: Home appliance showroom salespersons in Khulna City are diverse in their demographic profile. A total of forty (40) salespersons were interviewed. The salespersons' socio-demographic characteristics are presented in Table 6.1.

Table 6.1: Socio-demographic Characteristics of Salespersons

\begin{tabular}{|c|c|c|c|}
\hline Variables & $\begin{array}{c}\text { Frequency } \\
\text { (Percentage) }\end{array}$ & Variables & $\begin{array}{l}\text { Frequency } \\
\text { (Percentage }\end{array}$ \\
\hline Age (years) & \multicolumn{3}{|c|}{ Education } \\
\hline Below 25 & $19(47.5 \%)$ & HSC (=Grade 12) & $14(35 \%)$ \\
\hline $25-30$ & $16(40 \%)$ & Graduation & $18(45 \%)$ \\
\hline $31-35$ & $4(10 \%)$ & Masters & $8(20 \%)$ \\
\hline More than 35 & $1(2.5 \%)$ & & \\
\hline Gender & \multicolumn{3}{|c|}{ Years of Employment } \\
\hline Male & $38(95 \%)$ & Less than 3 years & $12(30 \%)$ \\
\hline Female & $2(5 \%)$ & $3-5$ years & $21(52.5 \%)$ \\
\hline & & More than 5 years & $7(17.5 \%)$ \\
\hline
\end{tabular}

Source: Author's compilation based on field survey, 2019

Table 6.1 explores that a majority of the salesperson working for home appliance showrooms in Khulna City are within the age limit of 30 years. However, the profession is still male dominated, especially in Khulna City. Compare to Dhaka, Khulna is far behind in respect of socio-cultural advancement. This might be a probable reason for less participation of female in sales profession in Khulna. Though Higher Secondary Certificate (equivalent to Grade 12 years of schooling) is the required educational qualification for the position, more than three-fifth of surveyed respondents are with higher educational qualification. The possible explanation of this fact is either the respondents willingly want to work as salesperson for a well-known brand home appliance showroom or they perceive that the job is well enough based on their academic performance/result in graduation or masters or in both. Majority of the respondents are working as salesperson for last five (5) years.

6.2 Daily Working Hours: The usual working hours per day is eight (8) hours according to Bangladesh Labor Act (BLA), 2006. However, all surveyed salespersons in all home appliance showrooms in Khulna City have to work beyond the stipulated time. The survey data reveals that $40 \%$ respondents have to work more than 8 hours a day but usually not more than 10 hours. The remaining $60 \%$ respondents report that they have to work more than 10 hours in day.

6.3 Ranking of Job Satisfaction Factors: Based on the model presented in analytical framework, the respondents were requested to rank the eight factors affecting job satisfaction in terms of importance to each salesperson for his/her job satisfaction. The result is presented in Table 6.2 .

\section{Table 6.2: Ranking of Job Satisfaction Factors}

\begin{tabular}{|c|c|c|c|}
\hline SL & Factors & $\begin{array}{l}\text { Frequency } \\
\text { (Percentage) }\end{array}$ & Ranking \\
\hline 1 & Salary \& Payments & $40(100 \%)$ & $1^{\text {st }}$ \\
\hline 2 & Work nature/Work itself & $25(62.5 \%)$ & $4^{\text {th }}$ \\
\hline 3 & Working conditions & $24(60 \%)$ & $5^{\text {th }}$ \\
\hline 4 & Organizational policies & $33(82.5 \%)$ & $2^{\text {nd }}$ \\
\hline 5 & Job security & $28(70 \%)$ & $3^{\text {rd }}$ \\
\hline 6 & Communication \& Cooperation & $22(55 \%)$ & $6^{\text {th }}$ \\
\hline 7 & Participation in management & $19(47.5 \%)$ & $7^{\text {th }}$ \\
\hline 8 & Performance evaluation & $16(40 \%)$ & $8^{\text {th }}$ \\
\hline
\end{tabular}

Source: Author's compilation based on field survey, 2019

Table 6.2 point outs that home appliance showroom salespersons rank "Salary \& payments", "Organizational policies" and "Job security" as $1^{\text {st }}, 2^{\text {nd }}$, and $3^{\text {rd }}$ respectively among the selected eight $(8)$ factors as the factors of job satisfaction. On the other hand, "Performance evaluation" and "Participative management" are the least influential factors of job satisfaction as ranked $8^{\text {th }}$ and $7^{\text {th }}$ respectively by the respondents. Hence, it can be 
concluded that "money" is still prime motivator and factor of job satisfaction. The remark is supported by another interesting finding from the Table 6.2 is that top three (3) ranked factors are directly/indirectly financial related, while the bottom three (3) ranked factors are directly non-financial.

6.4 Satisfaction with Salary \& Payments: The importance of pay as a factor in job satisfaction has been greatly over emphasized by management. Most studies have found that salary \& pay is ranked at top by the employees for job satisfaction. Three (3) questions were developed in questionnaire based on this factor and the results are summarized in Table 6.3 .

Table 6.3: Satisfaction with Salary \& Payments

\begin{tabular}{|c|c|c|c|c|c|c|}
\hline Variables & $\begin{array}{l}1 \\
\%\end{array}$ & $\begin{array}{c}2 \\
\%\end{array}$ & $\begin{array}{c}3 \\
\%\end{array}$ & $\begin{array}{l}4 \\
\%\end{array}$ & $\begin{array}{l}5 \\
\%\end{array}$ & $\begin{array}{l}\text { Mean } \\
\text { Value }\end{array}$ \\
\hline Salary & $\begin{array}{c}6 \\
15 \% \\
\end{array}$ & $\begin{array}{c}12 \\
30 \% \\
\end{array}$ & $\begin{array}{c}18 \\
45 \% \\
\end{array}$ & $\begin{array}{c}4 \\
10 \% \\
\end{array}$ & -- & $\begin{array}{r}2.5 \\
(100 / 40) \\
\end{array}$ \\
\hline Sales Bonus/Reward & $\begin{array}{c}2 \\
5 \%\end{array}$ & $\begin{array}{c}9 \\
22.5 \%\end{array}$ & $\begin{array}{c}16 \\
40 \% \\
\end{array}$ & $\begin{array}{c}8 \\
20 \%\end{array}$ & $\begin{array}{c}5 \\
12.5 \%\end{array}$ & $\begin{array}{r}3.13 \\
(125 / 40)\end{array}$ \\
\hline Over Time Benefits & $\begin{array}{c}9 \\
22.5 \% \\
\end{array}$ & $\begin{array}{c}12 \\
30 \%\end{array}$ & $\begin{array}{c}16 \\
40 \% \\
\end{array}$ & $\begin{array}{c}3 \\
7.5 \% \\
\end{array}$ & - & $\begin{array}{r}2.33 \\
(93 / 40) \\
\end{array}$ \\
\hline
\end{tabular}

Source: Author's compilation based on field survey, 2019

$1=$ Completely dissatisfied, $2=$ Dissatisfied, $3=$ Neutral, $4=$ Satisfied and $5=$ Completely satisfied.

Mean calculation for "Sales Bonus/Reward": $(1 * 2+2 * 9+3 * 16+4 * 8+5 * 5) / 40=125 / 40=3.13$

Table 6.3 figures out that salespersons working for home appliance showroom in Khulna City are not satisfied with their salary and payment such as sales bonus, extra work hour benefits. Among those variable, the respondents are almost dissatisfied with their overtime benefit. As more than half of the salespersons have to work more than 10 hours a day, they are not paid or under-paid for their extra work. It is also clear from Table 5.3 that $40 \%$ respondents are at neutral position. Any positive change in their payment system will enhance salespersons' job satisfaction, keeping the status-quo can create more dissatisfaction among them in long run.

6.5 Satisfaction with Work Itself: One of the important factors inherent in the job is type of work and job responsibilities. Home appliance showroom salespersons were asked whether they are satisfied with their work/job responsibilities or not and the responses are in Table 6.4.

Table 6.4: Satisfaction with Work Itself

\begin{tabular}{|l|c|c|c|c|c|c|}
\hline \multicolumn{1}{|c|}{ Variables } & $\mathbf{1}$ & $\mathbf{2}$ & $\mathbf{3}$ & $\mathbf{4}$ & $\mathbf{5}$ & $\begin{array}{c}\text { Mean } \\
\text { Value }\end{array}$ \\
\hline Work and & $\mathbf{\%}$ & $\mathbf{\%}$ & $\mathbf{\%}$ & $\mathbf{\%}$ & $\mathbf{\%}$ & 3.38 \\
Job Responsibility & 1 & 9 & 9 & 16 & 5 & $(135 / 40)$ \\
\hline
\end{tabular}

Source: Author's compilation based on field survey, 2019

$1=$ Completely dissatisfied, $2=$ Dissatisfied, $3=$ Neutral, $4=$ Satisfied and $5=$ Completely satisfied.

Mean calculation: $(1 * 1+2 * 9+3 * 9+4 * 16+5 * 5) / 40=135 / 40=3.38$

Table 6.4 evolves that more than half of the respondents are satisfied with their work and job responsibilities. As the job market is not expanding in Bangladesh, most of the people who get a job, and if it is in famous company, are very satisfied. However, just little less than half of total respondents belong to neutral and dissatisfied stage, the company can arrange regular training program to find interest in the job.

6.6 Satisfaction with Working Conditions: The organization must ensure a comfortable working condition suitable for its' human resources according to Bangladesh Labor Act (BLA), 2006. The respondents were requested to tell whether they are satisfied with working conditions and the result is shown in Table 6.5.

\section{Table 6.5: Satisfaction with Working Conditions}

\begin{tabular}{|c|c|c|c|c|c|c|}
\hline Variables & $\mathbf{1}$ & $\mathbf{2}$ & $\mathbf{3}$ & $\mathbf{4}$ & $\mathbf{5}$ & $\begin{array}{r}\text { Mean } \\
\text { Value }\end{array}$ \\
\hline Working Conditions & $\mathbf{\%}$ & $\mathbf{\%}$ & $\mathbf{\%}$ & $\mathbf{\%}$ & $\mathbf{\%}$ & 3.73 \\
& --- & 1 & 11 & 26 & 2 & $(149 / 40)$ \\
\hline
\end{tabular}

Source: Author's compilation based on field survey, 2019

$1=$ Completely dissatisfied, $2=$ Dissatisfied, $3=$ Neutral, $4=$ Satisfied and $5=$ Completely satisfied.

Mean calculation: $(2 * 1+3 * 11+4 * 26+5 * 2) / 40=149 / 40=3.73$

Table 6.5 evolves that almost three-fourth of the respondents are satisfied with their working conditions. Better working conditions are conducive to better productivity. The surveyed home appliance brands are leading the industry and hence, the showrooms are designed and decorated nicely as a means of attracting the customers. 
6.7 Satisfaction with Organizational Policies: An organization's policies are the operational foundation for all its business processes and management. Clear policies define the business protocol and ensure that all employees operate according to a consistent prearranged formula. Policies and procedures play a very important role by defining an organization's guiding principles, providing detailed task instructions and forming the basic structure of business operations. Five (5) questions were developed in questionnaire relating to organizational policies and the results are summarized in Table 6.6.

Table 6.6: Satisfaction with Organizational Policies

\begin{tabular}{|c|c|c|c|c|c|c|}
\hline Variables & $\begin{array}{l}1 \\
\% \\
\end{array}$ & $\begin{array}{c}2 \\
\% \\
\end{array}$ & $\begin{array}{c}3 \\
\% \\
\end{array}$ & $\begin{array}{c}4 \\
\% \\
\end{array}$ & $\begin{array}{l}5 \\
\% \\
\end{array}$ & $\begin{array}{l}\text { Mean } \\
\text { Value } \\
\end{array}$ \\
\hline Working Hours & $\begin{array}{c}4 \\
10 \%\end{array}$ & $\begin{array}{c}21 \\
52.5 \%\end{array}$ & $\begin{array}{c}7 \\
17.5 \%\end{array}$ & $\begin{array}{c}5 \\
12.5 \%\end{array}$ & $\begin{array}{c}3 \\
7.5 \%\end{array}$ & $\begin{array}{r}2.55 \\
(102 / 40)\end{array}$ \\
\hline Promotion Opportunity & --- & $\begin{array}{c}7 \\
17.5 \%\end{array}$ & $\begin{array}{c}13 \\
32.5 \%\end{array}$ & $\begin{array}{c}12 \\
30 \%\end{array}$ & $\begin{array}{c}8 \\
20 \%\end{array}$ & $\begin{array}{r}3.53 \\
(141 / 40)\end{array}$ \\
\hline $\begin{array}{l}\text { Training and } \\
\text { Career Development }\end{array}$ & --- & $\begin{array}{c}2 \\
5 \%\end{array}$ & $\begin{array}{c}3 \\
7.5 \%\end{array}$ & $\begin{array}{c}24 \\
60 \%\end{array}$ & $\begin{array}{c}11 \\
27.5 \%\end{array}$ & $\begin{array}{r}4.10 \\
(164 / 40)\end{array}$ \\
\hline $\begin{array}{l}\text { Leave } \\
\text { (Casual and Medical) }\end{array}$ & --- & --- & $\begin{array}{c}9 \\
22.5 \%\end{array}$ & $\begin{array}{c}20 \\
50 \%\end{array}$ & $\begin{array}{c}11 \\
27.5 \%\end{array}$ & $\begin{array}{r}4.05 \\
(162 / 40)\end{array}$ \\
\hline $\begin{array}{l}\text { Long term Benefit } \\
\& \text { Insurance }\end{array}$ & $\begin{array}{c}4 \\
10 \%\end{array}$ & $\begin{array}{c}6 \\
15 \%\end{array}$ & $\begin{array}{c}11 \\
27.5 \%\end{array}$ & $\begin{array}{c}13 \\
32.5 \%\end{array}$ & $\begin{array}{c}6 \\
15 \%\end{array}$ & $\begin{array}{r}3.28 \\
(131 / 40)\end{array}$ \\
\hline
\end{tabular}

Source: Author's compilation based on field survey, 2019

$1=$ Completely dissatisfied, $2=$ Dissatisfied, $3=$ Neutral, $4=$ Satisfied and $5=$ Completely satisfied.

Mean calculation for "Working Hours": $(1 * 4+2 * 21+3 * 7+4 * 5+5 * 3) / 40=102 / 40=2.55$

Table 6.6 figures out that salespersons working for home appliance showroom in Khulna City are not totally dissatisfied with organizational policies related to working hours, chances for promotion, training \& development, leave and long term employee benefits. The salespersons are more than satisfied in case of training \& career development and leave system. Though more than half of the respondents are dissatisfied with their working hours (60\% respondents report that they have to work more than 10 hours in day), the mean value is between "dissatisfied" and "neutral" state. Based on the research findings, the home appliance brands in Khulna City need to work on the organizational policies related to long term benefits and insurance.

6.8 Satisfaction with Job Security: An average employee will think of job security first rather than other factors to get settle in life. It has been seen that employees secured in job are more satisfied in their job. But security is of less importance to the better educated person, perhaps because there is not so much fear of layoff in the kind of jobs that the highly educated persons obtain, or the highly educated persons are more confident of being able to find other jobs if necessary. The responses from the showroom salespersons on their job security are in Table 6.7.

Table 6.7: Satisfaction with Job Security

\begin{tabular}{|c|c|c|c|c|c|r|}
\hline Variables & $\mathbf{1}$ & $\mathbf{2}$ & $\mathbf{3}$ & $\mathbf{4}$ & $\mathbf{5}$ & \multicolumn{1}{c|}{ Mean } \\
& $\mathbf{\%}$ & $\mathbf{\%}$ & $\mathbf{\%}$ & $\mathbf{\%}$ & $\mathbf{\%}$ & Value \\
\hline \multirow{2}{*}{ Job Security } & 1 & 4 & 17 & 11 & 7 & 3.48 \\
& $2.5 \%$ & $10 \%$ & $42.5 \%$ & $27.5 \%$ & $17.5 \%$ & $(139 / 40)$ \\
\hline
\end{tabular}

Source: Author's compilation based on field survey, 2019

$1=$ Completely dissatisfied, $2=$ Dissatisfied, $3=$ Neutral, $4=$ Satisfied and $5=$ Completely satisfied.

Mean calculation: $(1 * 1+2 * 4+3 * 17+4 * 11+5 * 7) / 40=139 / 40=3.48$

Table 6.7 points out little less than half of the respondents are satisfied with their security issue and little more than two-fifth respondents are in neutral position at this ground. The surveyed five (5) home appliance brands are with well reputation in the industry and two (2) of them are multinational; hence the job in those organization will be more secured than other organization. $30 \%$ of the respondents are working for less than 3 years, the researcher personally opined that this group of people are not yet permanent at the job and feel unsecured.

6.9 Satisfaction with Communication and Cooperation: One's associations have frequently been mentioned as a factor in job satisfaction. Certainly this seems reasonable as people want to be near their friends, support and cooperation in their daily work environment. Working for many years together brings a sense of mutual cooperation. Supervision is another important factors related to job satisfaction, which is correlated with factors that also are important in assessing job satisfaction of salesperson. Three (3) questions were developed in based on this factor with relation to \& support from colleagues, supervisor/showroom manager and complements from supervisor/showroom manager. The results are presented in Table 6.8 below. 
Table 6.8: Satisfaction with Communication and Cooperation

\begin{tabular}{|c|c|c|c|c|c|c|}
\hline Variables & $\begin{array}{l}1 \\
\%\end{array}$ & $\begin{array}{c}2 \\
\%\end{array}$ & $\begin{array}{c}3 \\
\%\end{array}$ & $\begin{array}{c}4 \\
\%\end{array}$ & $\begin{array}{l}5 \\
\%\end{array}$ & $\begin{array}{l}\text { Mean } \\
\text { Value }\end{array}$ \\
\hline Relation with \& Support from Colleagues & --- & $\begin{array}{c}3 \\
7.5 \%\end{array}$ & $\begin{array}{c}4 \\
10 \% \\
\end{array}$ & $\begin{array}{c}12 \\
18 \%\end{array}$ & $\begin{array}{c}21 \\
52.5 \%\end{array}$ & $\begin{array}{r}4.28 \\
(171 / 40) \\
\end{array}$ \\
\hline $\begin{array}{l}\text { Supervisor's/Showroom Manager's Instruction, Support } \\
\text { and Cooperation }\end{array}$ & --- & $\begin{array}{c}2 \\
5 \%\end{array}$ & $\begin{array}{c}7 \\
17.5 \%\end{array}$ & $\begin{array}{c}19 \\
47.7 \%\end{array}$ & $\begin{array}{c}12 \\
30 \% \\
\end{array}$ & $\begin{array}{r}4.03 \\
(161 / 40) \\
\end{array}$ \\
\hline Complements from Supervisor/Showroom Manager & --- & $\begin{array}{c}2 \\
5 \%\end{array}$ & $\begin{array}{c}5 \\
7.5 \%\end{array}$ & $\begin{array}{c}15 \\
37.5 \%\end{array}$ & $\begin{array}{c}18 \\
45 \%\end{array}$ & $\begin{array}{r}4.23 \\
(169 / 40)\end{array}$ \\
\hline
\end{tabular}

Source: Author's compilation based on field survey, 2019

$1=$ Completely dissatisfied, $2=$ Dissatisfied, $3=$ Neutral, $4=$ Satisfied and $5=$ Completely satisfied.

Mean calculation "Relation with \& Support": $(2 * 3+3 * 4+4 * 12+5 * 21) / 40=171 / 40=4.28$

Table 6.8 express that salespersons working for home appliance showroom in Khulna City are more than satisfied on the ground of relationship, communication, support and cooperation both from their colleagues and supervisor/showroom manager. The finding also explores that the showroom salespersons in Khulna City have a strong cohesiveness among them and support for each other.

6.10 Satisfaction with Participation in Management: Though participation in management requires education and adequate experiences about the organization, some sort of participation for managing the showroom operations and management is encouraging for salesperson. Through salespersons' participation, the management can get the real information and perspective of the customer. The salespersons were asked to rate their level of satisfaction regarding participation in showroom management and their responses are furnished in Table 6.9.

\section{Table 6.9: Satisfaction with Participation in Management}

\begin{tabular}{|l|c|c|c|c|c|r|}
\hline \multicolumn{1}{|c|}{ Variables } & $\mathbf{1}$ & $\mathbf{2}$ & $\mathbf{3}$ & $\mathbf{4}$ & $\mathbf{5}$ & \multicolumn{1}{c|}{$\begin{array}{c}\text { Mean } \\
\text { Value }\end{array}$} \\
\hline Participation & $\mathbf{\%}$ & $\mathbf{\%}$ & $\mathbf{\%}$ & $\mathbf{\%}$ & $\mathbf{\%}$ & 4.13 \\
in Management & --- & 2 & 5 & 19 & 14 & $(165 / 40)$ \\
\hline
\end{tabular}

Source: Author's compilation based on field survey, 2019

$1=$ Completely dissatisfied, $2=$ Dissatisfied, $3=$ Neutral, $4=$ Satisfied and $5=$ Completely satisfied.

Mean calculation: $(2 * 2+3 * 5+4 * 19+5 * 14) / 40=165 / 40=4.13$

Table 6.9 finds out that majority of the respondents are satisfied with their participation in showroom operation and management. As the salespersons directly work with the customers, they could be better sources of customer information, product positing and overall marketing strategies. Level of their participation in showroom management and operation will also enhance their capabilities and skills for future supervisors/showroom managers. If ensured, the salespersons will feel themselves as a part of the organization and their satisfaction will be increased.

6.11 Satisfaction with Performance Evaluation: Though the respondents ranked "performance evaluation" as the $8^{\text {th }}$ (last ranking) factors affecting the level of job satisfaction, this could be a crucial factor for those who wants equal treatment in work, timely promotion and career development within the prescribed organizational policies. Therefore, the respondents were requested to indicate their satisfaction level for performance evaluation system and the results are in Table 6.10.

Table 6.10: Satisfaction with Performance Evaluation

\begin{tabular}{|c|c|c|c|c|c|c|}
\hline Variables & $\mathbf{1}$ & $\mathbf{2}$ & $\mathbf{3}$ & $\mathbf{4}$ & $\mathbf{5}$ & $\begin{array}{c}\text { Mean } \\
\text { Value }\end{array}$ \\
\hline \multirow{2}{*}{ Performance Evaluation } & $\mathbf{\%}$ & $\mathbf{\%}$ & $\mathbf{\%}$ & $\mathbf{\%}$ & $\mathbf{\%}$ & 2.93 \\
& 4 & 9 & 16 & 8 & 3 & $(117 / 40)$ \\
\hline
\end{tabular}

Source: Author's compilation based on field survey, 2019

$1=$ Completely dissatisfied, $2=$ Dissatisfied, $3=$ Neutral, $4=$ Satisfied and $5=$ Completely satisfied.

Mean calculation: $(1 * 4+2 * 9+3 * 16+4 * 8+5 * 3) / 40=117 / 40=2.93$

Table 6.10 shows that the salespersons in home appliance showrooms in Khulna city are almost neutral (mean value 2.93) for organizational performance evaluation system. Eventually the gap between dissatisfied respondents $(32.5 \%)$ and satisfied respondents $(27.5 \%)$ is nominal. Performance evaluation system must be transparent for all sorts of financial benefits, promotion, training \& career development opportunities in the organization.

6.12 Overall Job Satisfaction: One of the specific objectives of the study is to assess job satisfaction level of home appliance showroom salespersons in Khulna City. To fulfill this objective, the respondents were asked that how satisfied they are (taking everything into account) with their job and the result is presented in Table 6.11. 


\begin{tabular}{|c|c|c|c|c|c|c|}
\hline \multicolumn{2}{|c|}{ Table 6.11: Overall Job Satisfaction } & & & & & \\
\hline Variables & $\begin{array}{l}1 \\
\%\end{array}$ & $\begin{array}{c}2 \\
\%\end{array}$ & $\begin{array}{c}3 \\
\%\end{array}$ & $\begin{array}{c}4 \\
\%\end{array}$ & $\begin{array}{l}5 \\
\%\end{array}$ & $\begin{array}{l}\text { Mean } \\
\text { Value }\end{array}$ \\
\hline $\begin{array}{l}\text { Overall } \\
\text { Job Satisfaction }\end{array}$ & --- & $\begin{array}{c}3 \\
7.5 \%\end{array}$ & $\begin{array}{c}8 \\
20 \%\end{array}$ & $\begin{array}{c}21 \\
52.5 \%\end{array}$ & $\begin{array}{c}8 \\
20 \%\end{array}$ & $\begin{array}{r}3.85 \\
(154 / 40)\end{array}$ \\
\hline
\end{tabular}

Source: Author's compilation based on field survey, 2019

$1=$ Completely dissatisfied, $2=$ Dissatisfied, $3=$ Neutral, $4=$ Satisfied and $5=$ Completely satisfied.

Mean calculation: $(2 * 3+3 * 8+4 * 21+5 * 8) / 40=154 / 40=3.85$

Table 6.11 evolves that almost three-fourth $(72.5 \%)$ of the salespersons working for various home appliance showrooms in Khulna City are satisfied with their job, taking everything into account. Any further initiatives, either in policy aspect or payment aspect, by the surveyed organizations will surely bring into a new height as the "Industry Best Employer".

\section{Research Findings}

Job satisfaction is the result of effect of so many factors. The terms are highly personalized, as the level of satisfaction differs from time to time and situation. Moreover, the attitude of any employee affects a lot. One gets satisfaction in any of the activities depending upon how he/she perceives the situation and what is expected in exchange of effort. There may be the difference between two employees, working at a different place and on different cadres. It all depends upon viewing of the situation and the effect of rest of the factors which are crucial at any point of time. The major findings of this study are as follows:

$\checkmark$ Majority of the salesperson working for home appliance showrooms are within the age limit of 30 years, working as salesperson for last five (5) years and the profession is still male dominated in Khulna City.

$\checkmark \quad$ A big part of the salespersons working for various home appliance showrooms in Khulna City are satisfied with their job, taking everything into account.

$\checkmark$ The salespersons rank "salary \& payments", "organizational policies" and "job security" as top three factors of job satisfaction.

$\checkmark \quad$ The study also finds that the showroom salespersons are not satisfied with their present salary and payments such as sales bonus, extra work hour benefits with a mean value of 2.65 which is still on the line of dissatisfaction and below "neutral" state of mind-set.

$\checkmark$ All salespersons, no matter in which brand showroom, have to work more than eight hours in a day but more than half of them are dissatisfied with the organizational policy for over time/extra work benefit.

$\checkmark$ Salespersons in home appliance showroom are more than satisfied on the ground of relationship, communication, support and cooperation both from their colleagues and supervisor/showroom manager.

$\checkmark$ Salespersons in home appliance showrooms in Khulna city are almost neutral (mean value 2.93) for organizational performance evaluation system as factor of job satisfaction.

$\checkmark$ Most of the salespersons do not see employee participation as a driver of better employee performance. The respondents rank "participation in management" as one of the least influencing factors for job satisfaction.

\section{Recommendations \& Conclusion}

The impact of job satisfaction in the performance of salespersons is an implicit issue. Satisfied employees always motivated to perform their job in a better way as well as they are highly committed to the organization. The study on the salespersons working for different home appliance showrooms in Khulna City reveals that though salespersons showed their overall attitudes approaching to satisfaction (mean value 3.85), there are some recommendations, based on the study findings, for taking into consideration:

$\checkmark$ The showroom managers as well as the supervisor have the responsibility for creating a high level of job satisfaction. The aim of leadership should be to increase the level of satisfaction which leads to higher performance in terms of sales, customer satisfaction and customer retention.

$\checkmark$ The organization should keep an eye on the salary \& payment structure, as study reveals it as the top ranked factor for satisfaction. In addition, that many respondents are not satisfied with their salary and payments. So, the company should try to provide the competitive pay structure considering industry situation.

$\checkmark \quad$ Financial benefits (specifically money) are a good motivator, actually all employees' work for money, employee needs the money; a good salary and good compensations are key factors in satisfying the employee. As the salespersons rank "salary \& payments" at top for job satisfaction and they are not satisfied with the extra work benefits, the organizations need to restructure/review their "salary and payments" policies.

$\checkmark$ To improve fairness in showroom salespersons satisfaction, the management needs to create a scientific performance appraisal system. Utilize the other developed countries' scientific performance systems, and 
use these systems to evaluate employee work performance and evaluate employee service quality.

Job satisfaction is a heavily researched area of inquiry. The objective was to assess the extent to which showroom salespersons are satisfied. Changes in organizational variables, such as pay scales, employee input in policy development, and work environment could be made in an effort to increase organizational commitment which in turn will lead to employee commitment and satisfaction. Job satisfaction plays a very positive role in the development of conducive environment of any organization. Therefore, identifying and measuring job satisfaction determinants are essential for overcoming job dissatisfaction and increasing the effectiveness in showroom management and sales performance. According to the findings of the study, the job satisfaction of showroom salespersons is significantly dependent upon salary \& payment, organizational policies and job security. It is also revealed that each of their determinants has significant positive relation with the overall job satisfaction of the salespersons. Therefore, increase in values/standard of each of these determinants would definitely increase the level of job satisfaction. Showroom salespersons job satisfaction can improve showroom sales, customer service and customer retention; hence, the financial performance of the organization. In this circumstance, policy makers and managers need to turn their attention to provide different kinds of facilities to their employees, if they want to enhance their businesses.

\section{References}

Davis, K. and Newstrom, J.W. (1997). Organizational Behavior: Human Behavior at Work, $11^{\text {th }}$ edition, pp. 208210. McGraw-Hill, New York.

Field, J. (2008). Job Satisfaction Model. Retrieved from http://talentedapps.wordpress.com/2008/04/11/jobsatisfaction-model-for-retention/.

Hakim (1993). Boost Morale to Gain Productivity, HR Magazine, February: 46-53

Haque M.E. and Islam M.M. (2003). Absenteeism, Job Stress and Mental Health of Manufacturing Workers in Bangladesh: A Comparative Study of Private and Public Sector Organization”, Journal of Business Studies, Vol-1 No.2.

Herzberg, F. (1966). Work and the Nature of Man, Cleveland: World Publishing.

Hoppock, R. (1935), “Job Satisfaction”, Harper and Brothers, New York, Pp. 47.

Judge, T. A., and Church, A. H. (2000). Job Satisfaction: Research and Practice. In C. L. Cooper \& E. A. Locke (Eds.), Industrial and organizational psychology: Linking theory with practice (pp. 166-198). Oxford, UK: Blackwell.

Jurgensen, C. E. (1978). Job preferences (What Makes a Job Good or Bad?), Journal of Applied Psychology, pp. $267-276$.

Khaleque, A. (1984). Job Satisfaction and Work in Industry, $5^{\text {th }}$ edition, Alamgir Art Press, Dhaka, pp. 27-34

Korman, A.A. (1991). Industrial Psychology and Organization, Translated by Hassan Shokrkon, Tehran, Roshd.

Lincoln, J.R. (1989). Employee Work Attitudes and Management Practice in the U.S and Japan: Evidence from a Large Comparative Study, California Management Review: 89-106.

Mobey and Locke, E. A. (1970). Job Satisfaction and Performance: A Theoretical Analysis, Organizational Behavior and Human Performance, Academic Press Inc., 5(5), pp. 484-500.

Modway, R.T. 1981, Veiwing Turnover from the perspective of those who remain. The relationship of job attitudes to attributions of the cause of turnover. Journal of Applied Psychology, 66, 120-123.

Porter, L.W. and Lawler, E.E. (1967). The Effect of Performance on Job Satisfaction, Industrial Relations, pp. 2028.

Robbins, S.P. (1997). Organizational Behavior, Prentice Hall, USA.

Siddika, T.M. (2012). Job Satisfaction: A Study on Civil Servants Working at the Field Level in Bangladesh, Unpublished Master's Thesis, Department of General and Continuing Education, North South University, Dhaka, Bangladesh.

Smith, P. C., Kendall, L. M., and Hulin, C. L. (1969). The Measurement of Satisfaction in Work and Retirement, Chicago: Rand-McNally.

Tasnim, S. (2006). Job Satisfaction among Female Teachers: A Study on Primary Schools in Bangladesh. M.Phil. Thesis, University of Bergen, Bergen, Norway.

Md. Anisur Rahman was born in Khulna, Bangladesh in 1977. He did his $1^{\text {st }}$ Master degree in Business Management from Northeast Normal University, China in 2006. Later on he completed his $2^{\text {nd }}$ Master degree in Development Studies from Khulna University, Bangladesh in 2014. He also has 1-year post-graduation diploma in HRM (Human Resources Management) from Bangladesh Institute of Management. At present, he is teaching as Senior Lecturer in the Department of Business Administration, North Western University, Khulna. Earlier, he also taught at Pingdingshan University, Henan, China in the College of International Education and Exchange as a Foreign Faculty for 5 years. Prior to joining North Western University, he worked for Hua Xiang Jute Products Co. Ltd. (100\% foreign investment), Mongla Export Processing Zone, Bagerhat, Bangladesh as Project 
Coordinator. Mr. Rahman is fluent in speaking Chinese and works a freelancer, consultant for Chinese businesses in Bangladesh. His research interest includes employee satisfaction, work environment \& leadership, human capital development, online business, consumer behavior and microcredit. 